\title{
PEMIMPIN YANG MELAYANI DALAM MEMBANGUN BANGSA YANG MANDIRI
}

\author{
(A Serving Leader In Developing Independent Nation)
}

\author{
ASEP SOLIKIN ${ }^{1)}$, H.M FATCHURAHMAN ${ }^{1)}$, SUPARDI') \\ 1) Program Studi Bimbingan dan Konseling Fakultas Keguruan dan IImu Pendidikan \\ ${ }^{2)}$ Program Studi Pendidikan Guru Sekolah Dasar Fakultas Keguruan dan IImu Pendidikan \\ Universitas Muhammadiyah Palangkaraya \\ JI. RTA Milono Km.1,5 Palangka Raya, Kalimantan Tengah 73111
}

Email: asep.solikin@yahoo.com, mfatchurahman789@gmail.com, supardi242@gmail.com

\begin{abstract}
Leadership is a person's ability to convince and motivate others to do something that are related to the common goals. The leadership involved the process of convincing in determining the goal of organization, motivating the attitude of the participator to reach the goal, convincing to improve their group and culture.

Leadership is a formal position, that ask to get facilities and services from the constituents that should be served. Although among the leaders that when they are inaugurated said that the position is a trust, but in fact, there is very little or it can be said almost no leader that truly implementing the leadership from their heart, that is a serving leader. Even that needs to be a note here is how a leader must have a vision in building an independent soul, views, thoughts, attitudes and behaviours of all of the people at one the leader in order to be oriented to the progress and modern, so Indonesia become a big nation and be able to have competition with the other nations in the world.

A truly leader always worked hard to improve himself before the leader busy to improve the others. The leader is not only a title or position that given from the outside but something that it grows and evolves from the inside of the person.
\end{abstract}

Kata Kunci : Leadership, nawacita, service

\section{ABSTRAK}

Kepemimpinan adalah kemampuan seseorang mempengaruhi dan memotivasi orang lain untuk melakukan sesuatu sesuai tujuan bersama. Kepemimpinan meliputi proses mempengaruhi dalam menentukan tujuan organisasi, memotivasi perilaku pengikut untuk mencapai tujuan, mempengaruhi untuk memperbaiki kelompok dan budayanya.

Kepemimpinan adalah jabatan formal, yang menuntut untuk mendapat fasilitas dan pelayanan dari konstituen yang seharusnya dilayani. Meskipun banyak di antara pemimpin yang ketika dilantik mengatakan bahwa jabatan adalah sebuah amanah, namun dalam kenyataannya sedikit sekali atau bisa dikatakan hampir tidak ada pemimpin yang sungguh-sungguh menerapkan kepemimpinan dari hati, yaitu kepemimpinan yang melayani. Bahkan yang perlu menjadi catatan saat ini adalah bagaimana seorang pemimpin harus memiliki visi dalam membangun jiwa yang merdeka, mengubah cara pandang, pikiran, sikap, dan perilaku seluruh rakyat sekaligus pemimpinnya agar berorientasi pada kemajuan dan hal-hal yang modern, sehingga Indonesia menjadi bangsa yang besar dan mampu berkompetisi dengan bangsabangsa lain di dunia.

Seorang pemimpin sejati selalu bekerja keras memperbaiki dirinya sebelum sibuk memperbaiki orang lain. Pemimpin bukan sekedar gelar atau jabatan yang diberikan dari luar melainkan sesuatu yang tumbuh dan berkembang dari dalam diri seseorang.

Kata Kunci: Kepemimpinan, Nawacita, Melayani 


\section{PENDAHULUAN}

Bangsa Indonesia akhir-akhir ini begitu banyak mengalami guncangan tiada henti. Guncangan ekonomi karena ketidakstabilan perekonomian global, teror dalam skala internasional yang berdampak pada perekonomian global dan melemahnya kepercayaan investor, serta permasalahan politik dalam negeri karena kepentingan sesaat politisi yang mencari keuntungan bagi diri dan kelompoknya. Sudah 16 tahun Bangsa Indnesia melewati masa reformasi, dengan harapan yang luar biasa dalam menanti sebuah kepemimpinan yang membawa bangsa ini lebih baik dan sejahtera.

Sejak bergulirnya masa reformasi, dimana demokrasi terbuka begitu lebar dan kebebasan berekspresi menjadi ciri utama era ini. Setidaknya empat orang presiden antara 1998 dan 2014 telah memimpin bangsa ini. Presiden B.J. Habibie, K.H. Abdurrahman Wahid, Megawati Soekarnoputri sampai Susilo Bambang Yudhonoyo (SBY), Indonesia telah mencatat sejumlah kemajuan di bidang ekonomi dan politik. Mereka memimpin di bawah bendera reformasi yang didukung oleh pemerintahan yang dipilih oleh rakyat melalui proses yang demokratis panjang dan begitu melelahkan.

Begitu gegap gempita kepemimpinan yang mereka berikan dengan berbagai macam karakter serta keberhasilan yang telah mereka berikan. Setidaknya terlihat bahwa ekonomi semakin berkembang dan masyarakat banyak yang bertambah makmur. Bahkan belum lama ini, Indonesia dikabarkan pada sisi ekonomi sudah masuk pada 10-besar dunia. Selain itu bidang politik, masyarakat sudah banyak menikmati kebebasan serta hak-haknya dibandingkan sebelumnya, termasuk di antaranya kemampuan mereka untuk melakukan pergantian pimpinannya secara periodik melalui pemilu yang demokratis. Bahkan kemungkinan tidak ada negara di muka bumi ini yang melebihi ramainya hiruk pikuk demokrasi Indonesia.

Pertanyaan besar kemudian juga muncul bagi pengamat yang senang melakukan pengamatan secara arif. Apakah para pemimpin bangsa ini melihat dan merasakan kegalauan masyarakat melalui protes di jalan-jalan di kota besar dan kecil, dan juga di ruang publik lainnya, termasuk media massa dan media sosial. Ada semacam paradoks yang sangat mencolok ketika Indonesia dijadikan model keberhasilan reformasi yang menghantarkan kebebasan politik serta demokrasi bersama pembangunan ekonomi bagi masyarakatnya. Fenomena apa ini sesungguhnya? Sesungguhnya Bangsa ini tidak terlalu goyah arah dan tujuan utamanya kalau pemimpin yang sedang menahkodai bansa ini mengerti apa yang diinginkan rakyat bangsa yang sangat besar ini.

Manusia adalah makhluk sosial yang tidak dapat hidup sendiri. Dalam hidup, manusia selalau berinteraksi dengan sesama serta dengan lingkungan. Manusia hidup berkelompok baik dalam kelompok besar maupun dalam kelompok kecil. Hidup dalam kelompok tentulah tidak mudah. Untuk menciptakan kondisi kehidupan yang harmonis anggota kelompok haruslah saling menghormati dan menghargai. Keteraturan hidup perlu selalu dijaga. Hidup yang teratur adalah impian setiap insan. Menciptakan \& menjaga kehidupan yang harmonis adalah tugas manusia. Manusia adalah makhluk Tuhan yang paling tinggi 
dibanding makhluk Tuhan lainnya. Manusia di anugerahi kemampuan untuk berpikir, kemampuan untuk memilah dan memilih mana yang baik \& mana yang buruk. Dengan kelebihan itulah manusia seharusnya mampu mengelola lingkungan dengan baik.

Tidak hanya lingkungan yang perlu dikelola dengan baik, kehidupan social manusia pun perlu dikelola dengan baik. Untuk itulah dibutuhkan sumber daya manusia yang berkualitas. Sumber daya yang berjiwa pemimpin, paling tidak untuk memimpin dirinya sendiri. Dengan berjiwa pemimpin manusia akan dapat mengelola diri, kelompok \& lingkungan dengan baik. Khususnya dalam penanggulangan masalah yang relatif pelik \& sulit. Disinilah dituntut kearifan seorang pemimpin dalam mengambil keputusan agar masalah dapat terselesaikan dengan baik. Dari pemaparan yang penulis uraikan di atas, banyak permasalahan yang penulis dapatkan. Permasalahan tersebut antara lain: Bagaimana hakikat menjadi seorang pemimpin?, Teori - teori untuk menjadi pemimpin yang baik?, dan bagaimana menjadi pemimpin yang efektif dalam melayani?,

\section{Hakikat Pemimpin}

Dalam kehidupan sehari - hari, baik di lingkungan keluarga, organisasi, perusahaan sampai dengan pemerintahan sering kita dengar sebutan pemimpin, kepemimpinan serta kekuasaan. Ketiga kata tersebut memang memiliki hubungan yang berkaitan satu dengan lainnya. Para ahli memaknai konsep pemimpin sebagai seseorang dengan wewenang kepemimpinannya mengarahkan bawahannya untuk mengerjakan sebagian dari pekerjaannya dalam mencapai tujuan. Stephen Robbins, misalnya mendefinisikan kepemimpinan sebagai "... the ability to influence a group toward the achievement of goals.".. Kepemimpinan adalah kemampuan untuk mempengaruhi suatu kelompok guna mencapai serangkaian tujuan (Stephen P. Robbins, 2003:130).

Kepemimpinan juga dimaknai sebagai proses mempengaruhi tidak hanya dari pemimpin kepada pengikut atau satu arah melainkan timbal balik atau dua arah. Pengikut yang baik juga dapat saja memunculkan kepemimpinan dengan mengikuti kepemimpinan yang ada dan pada derajat tertentu memberikan umpan balik kepada pemimpin. Pengaruh adalah proses pemimpin mengkomunikasikan gagasan, memperoleh penerimaan atas gagasan, dan memotivasi pengikut untuk mendukung serta melaksanakan gagasan tersebut lewat "perubahan. (Robert N. Lussier and Christopher F. Achua, 2010:6.)

Bahkan kepemimpinan bisa diartikan sebagai sebuah proses untuk mempengaruhi orang lain agar mampu memahami serta menyetujui apa yang harus dilakukan sekaligus bagaimana melakukannya, termasuk pula proses memfasilitasi upaya individu atau kelompok dalam memenuhi tujuan bersama. (Gary Yukl, 2009:26)

Dalam menggunakan wewenang formal pemimpin dimaknai pada upaya mengorganisasikan, mengarahkan, mengontrol para bawahan yang bertanggung jawab, supaya semua bagian pekerjaan dikoordinasi demi mencapai tujuan. Bahkan kalau menelisik dari karakternya pemimpin pertama-tama haruslah seorang yang mampu menumbuhkan dan mengembangkan segala yang terbaik dalam diri para bawahannya. 
Seorang pemimpin boleh berprestasi tinggi untuk dirinya sendiri, tetapi itu tidak memadai apabila ia tidak berhasil menumbuhkan dan mengembangkan segala yang terbaik dalam diri para bawahannya. Dari begitu banyak definisi mengenai pemimpin, dapat penulis simpulkan bahwa : Pemimpin adalah orang yang mendapat amanah serta memiliki sifat, sikap, dan gaya yang baik untuk mengurus atau mengatur orang lain.

Kajian ini pun pada akhirnya harus mendudukan secara benar antara pemimpin dengan dengan penguasa dan kepemimpinan dengan kekuasaan. Hal ini menjadi penting karena konteks kepemimpinan adalah kemampuan seseorang mempengaruhi dan memotivasi orang lain untuk melakukan sesuatu sesuai tujuan bersama yang meliputi proses mempengaruhi dalam menentukan tujuan organisasi, memotivasi perilaku pengikut untuk mencapai tujuan, mempengaruhi untuk memperbaiki kelompok dan budayanya. Sedangkan kekuasaan adalah kemampuan untuk mempengaruhi orang lain untuk mau melakukan apa yang diinginkan pihak lainnya. Kepemimpinan adalah seni untuk mempengaruhi dan menggerakkan orang - orang sedemikian rupa untuk memperoleh kepatuhan, kepercayaan, respek, dan kerjasama secara royal untuk menyelesaikan tugas sementara kekuasaan adalah kemampuan untuk mempengaruhi orang lain untuk mau melakukan apa yang diinginkan pihak lainnya.

\section{Teori Kepemimpinan}

Memahami teori-teori kepemimpinan sangat besar artinya untuk mengkaji sejauh mana kepemimpinan dalam suatu organisasi telah dapat dilaksanakan secara efektif serta menunjang kepada produktifitas organisasi secara keseluruhan. Dalam tulisan ini akan dibahas tentang teori dan gaya kepemimpinan. Seorang pemimpin harus mengerti tentang teori kepemimpinan agar nantinya mempunyai referensi dalam menjalankan sebuah organisasi.

Beberapa teori tentang kepemimpinan antara lain

\section{a. Teori Kepemimpinan Sifat ( Trait Theory )}

Presiden pertama Republik Indonsia Dr. Ir. Soekarno dalam pandangan penulis adalah sosok yang masuk dalam kategori ini. Teori ini menyebutkan bahwa pemimpin itu dilahirkan (given) bukan dilatih, dibentuk, disiapkan atau diasah dengan training-training yang keras. Teori kepemimpinan sifat berkembang dan populer pertama kali di Negeri Yunani Kuno dan Romawi yang beranggapan bahwa pemimpin itu dilahirkan, bukan diciptakan yang kemudian teori ini dikenal dengan "The Greatma Theory".

Peter G. Northouse menyimpulkan sifatsifat yang melekat pada diri seorang pemimpin yang melakukan kepemimpinan (menurut pendekatan sifat) adalah sifat-sifat berikut:

1. Intelijensi- Pemimpin cenderung punya intelijensi dalam hal kemampuan bicara, menafsir, dan bernalar yang lebih kuat ketimbang yang bukan pemimpin.

2. Kepercayaan Diri- Kepercayaan diri adalah keyakinan akan kompetensi dan keahlian yang dimiliki, dan juga meliputi harga diri serta keyakinan diri. 
3. Determinasi- Determinasi adalah hasrat menyelesaikan pekerjaan yang meliputi ciri seperti berinisiatif, kegigihan, mempengaruhi, dan cenderungmenyetir.

4. Integritas - Integritas adalah kualitas kujujuran dan dapat dipercaya. Integritas membuat seorang pemimpin dapat dipercaya dan layak untuk diberi kepercayaan oleh para pengikutnya.

5. Sosiabilitas - Sosiabilitas adalah kecenderungan pemimpin untuk menjalin hubungan yang menyenangkan. Pemimpin yang menunjukkan sosiabilitas cenderung bersahabat, ramah, sopan, bijaksana, dan diplomatis. Mereka sensitif terhadap kebutuhan orang lain dan menunjukkan perhatian atas kehidupan mereka. (http:// setabasri01. blogspot.co.id/2011/01/ kepemim-pinandalam-organisasi. html)

\section{b. Teori Kepemimpinan Situasi}

Pendekatan ini dikembangkan oleh Paul Hersey and Kenneth $\mathrm{H}$. Blanchard tahun 1969 berdasarkan Teori Gaya Manajemen Tiga Dimensi karya William J. Reddin tahun 1967. Pendekatan kepemimpinan Situasional fokus pada fenomena kepemimpinan di dalam suatu situasi yang unik. Premis dari pendekatan ini adalah perbedaan situasi membutuhkan gaya kepemimpinan yang berbeda. Dari cara pandang ini, seorang pemimpin agar efektif harus mampu menyesuaikan gaya mereka terhadap tuntutan situasi yang berubah-ubah. Pendekatan kepemimpinan situasional menekankan bahwa kepemimpinan terdiri atasdimensi arahan dan dimensi dukungan. Setiap dimensi harus diterapkan secara tepat dengan memperhatikan situasi yang berkembang. Guna menentukan apa yang dibutuhkan oleh situasi khusus, pemimpin harus mengevaluasi pekerja mereka dan menilai seberapa kompeten dan besar komitmen pekerja atas pekerjaan yang diberikan

Perilaku seorang pemimpin yang mendasarkan teori ini memiliki kecendrungan kearah dua hal yaitu; Pertama yang disebut dengan Konsiderasi yaitu kecendrungan seorang pemimpin yang menggambarkan hubungan akrab dengan bawahan. Contoh gejala yang ada dalam hal ini seperti : membela bawahan, memberi masukan kepada bawahan dan bersedia berkonsultasi dengan bawahan, dan kedua; Kedua disebut Struktur Inisiasi yaitu Kecendrungan seorang pemimpin yang memberikan batasan kepada bawahan. Contoh yang dapat dilihat, bawahan mendapat instruksi dalam pelaksanaan tugas, kapan, bagaimana pekerjaan dilakukan, dan hasil yang akan dicapai.

Jadi, berdasarkan teori ini, seorang pemimpin yang baik adalah bagaimana seorang pemimpin yang memiliki perhatian yang tinggi kepada bawahan dan terhadap hasil yang tinggi pula.

\section{e. Teori Kelompok.}

Gaya ini lebih menekankan pada upaya memberi tekanan seimbang, baik pada pekerjaan ataupun hubungan antarpersonal. Gaya ini mendorong derajat partisipasi dan kerja tim yang tinggi di dalam organisasi sehingga mampu memuaskan kebutuhan dasar pekerja agar mereka tetap merasa terlibat dan punya komitmen kuat dalam 
pekerjaannya. Kata yang dapat menggambarkan pemimpin yang menerapkangaya manajemen tim adalah : menstimulir, partisipatif, penentu tindakan, pembuka isu, penjelas prioritas, pembuat terobosan, bersikap terbuka, dan penikmat pekerjaan. Agar tujuan kelompok (organisasi) dapat tercapai, harus ada pertukaran yang positif antara pemimpin dengan pengikutnya.

Tim adalah kelompok di dalam organisasi yang anggota-anggotanya saling bergantung satu sama lain, saling berbagi tujuan bersama, dan dicirikan oleh adanya satu orang yang mengkoordinasikan kegiatan bersama mereka. Koordinasi tersebut dilakukan demi mencapai tujuan bersama. Contoh dari sebuah tim adalah tim manajemen proyek, gugus tugas, unit-unit kerja, atau tim pengembang organisasi. Di dalam tim, fungsi utama kepemimpinan adalah berupaya mencapai tujuan organisasi (tim) secara kolektif, bukan individual. Tim umumnya memiliki seorang pemimpin yang telah ditentukan. Pemimpin tersebut dapat berasal dari dalam tim itu sendiri maupun dari luar.

Peran kepemimpinan di dalam tim dapat saja dirotasi sehingga mungkin saja diisi oleh para anggota lain antarwaktu. Peran kepemimpinan di dalam tim juga bisa disebar di antara sejumlah anggota tim tanpa harus ditentukan seorang pemimpin secara formal. Kepemimpinan yang tersebar tersebut umum ditemukan dalam kepemimpinan tim. Posisi kepemimpinan dalam tim tidak lagi bercorak satu pemimpin formal selaku pemegang tanggung jawab utama melainkan jatuh ke tangan beberapa orang yang berpengalaman di dalam tim. (George R. Goethals, ed, 2004: 1529)

Banyak studi yang sudah dilakukan untuk melihat gaya kepemimpinan seseorang. Salah satunya yang terkenal adalah yang dikemukakan oleh Blanchard, yang mengemukakan 4 gaya dari sebuah kepemimpinan. Gaya kepemimpinan ini dipengaruhi oleh bagaimana cara seorang pemimpin memberikan perintah, dan sisi lain adalah cara mereka membantu bawahannya. Keempat gaya tersebut adalah;

1. Directing; Gaya tepat apabila kita dihadapkan dengan tugas yang rumit dan staf kita belum memiliki pengalaman dan motivasi untuk mengerjakan tugas tersebut. Atau apabila anda berada di bawah tekanan waktu penyelesaian. Kita menjelaskan apa yang perlu dan apa yang harus dikerjakan. Dalam situasi demikian, biasanya terjadi overcommunicating (penjelasan berlebihan yang dapat menimbulkan kebingungan dan pembuangan waktu). Dalam proses pengambilan keputusan, pemimpin memberikan aturan -aturan dan proses yang detil kepada bawahan. Pelaksanaan di lapangan harus menyesuaikan dengan detil yang sudah dikerjakan.

2. Coaching; Gaya ini dikenal dengan gaya Pemberitahu. Gaya pemimpin yang selalu memberikan instruksi yang jelas, arahan yang rinci, serta mengawasi pekerjaan dari jarak dekat. Gaya Pemberitahu membantu untuk memastikan pekerja yang baru untuk menghasilkan kinerja yang maksimal, dan 
akan menyediakan fundasi solid bagi kepuasan dan kesuksesan mereka di masa datangPemimpin tidak hanya memberikan detil proses dan aturan kepada bawahan tapi juga menjelaskan mengapa sebuah keputusan itu diambil, mendukung proses perkembangannya, dan juga menerima barbagai masukan dari bawahan. Gaya yang tepat apabila staf kita telah lebih termotivasi dan berpengalaman dalam menghadapi suatu tugas. Disini kita perlu memberikan kesempatan kepada mereka untuk mengerti tentang tugasnya, dengan meluangkan waktu membangun hubungan dan komunikasi yang baik dengan mereka.

3. Supporting; Sebuah gaya dimana pemimpin memfasiliasi dan membantu upaya bawahannya dalam melakukan tugas. Dalam hal ini, pemimpin tidak memberikan arahan secara detail, tetapi tanggung jawab dan proses pengambilan keputusan dibagi bersama dengan bawahan. Gaya ini akan berhasil apabila karyawan telah mengenal teknik - teknik yang dituntut dan telah mengembangkan hubungan yang lebih dekat dengan anda. Dalam hal ini kita perlumeluangkan waktu untuk berbincang - bincang, untuk lebih melibatkan mereka dalam penganbilan keputusan kerja, serta mendengarkan saran - saran mereka mengenai peningkatan kinerja.

4. Delegating; Gaya Pendelegasiadalah gaya pemimpin yang cenderung mengalihkan tanggung jawab atas proses pembuatan keputusan dan pelaksanaannya. Gaya ini muncul tatkala pekerja ada pada tingkat kesiapan tertinggi sehubungan dengan pekerjaannya. Gaya ini efektif karena pengikut dianggap telah kompeten dan termotivasi penuh untuk mengambil tanggung jawab atas pekerjaannya.

Keempat gaya ini tentu saja mempunyai kelemahan dan kelebihan, serta sangat tergantung dari lingkungan di mana seorang pemimpin berada, dan juga kesiapan dari bawahannya. Maka kemudian timbul apa yang disebut sebagai "situational leadership". Situational leadership mengindikasikan bagaimana seorang pemimpin harus menyesuaikan keadaan dari orang - orang yang dipimpinnya.

Ditengah - tengah dinamika organisasi (yang antara lain diindikasikan oleh adanya perilaku staf / individu yang berbeda - beda), maka untuk mencapai efektivitas organisasi, penerapan keempat gaya kepemimpinan diatas perlu disesuaikan dengan tuntutan keadaan. Inilah yang dimaksud dengan situasional lesdership,sebagaimana telah disinggung di atas. Yang perlu diperhatikan adalah bahwa untuk dapat mengembangkan gaya kepemimpinan situasional ini, seseorang perlu memiliki tiga kemampuan khusus yakni

a. Kemampuan analitis (analytical skills) yakni kemampuan untuk menilai tingkat pengalaman dan motivasi bawahan dalam melaksanakan tugas. 
b. Kemampuan untuk fleksibel (flexibility atau adaptability skills) yaitu kemampuan untuk menerapkan gaya kepemimpinan yang paling tepat berdasarkan analisa terhadap situasi.

c. Kemampuan berkomunikasi (communication skills) yakni kemampuan untuk menjelaskan kepada bawahan tentang perubahan gaya kepemimpinan yang kita terapkan.

\section{METODOLOGI}

Kajian ini menggunakan pendekatan kualitatif dengan jenis penelitian deskriptif. Budge dan Taylor mendefinisikan metode kualitatif sebagai prosedur penelitian yang menggunakan data deskriptif berupa kata-kata tertulis atau lisan dari orang-orang atau perilaku yang diamati (Lexi J. Moleong, 2002)

Selanjutnya penelitian deskriptif digunakan untuk memecahkan atau menjawab permasalahan yang sedang dihadapi pada situasi sekarang. Dilakukan dengan menempuh langkahlangkah pengumpulan, klasifikaasi dan analisis data, membuat kesimpulan dan laporan, dengan tujuan utama untuk membuat gambaran tentang suatu keadaan secara obyektif dalam satu deskripsi situasi (M. Ali, 1987) Tidak berbeda dengan pernyataan Imran Arifin yang menyebutkan ciri-ciri pendekatan kualitatif ada lima: 1. Mempunyai latar alami sebagai sumber data dan peneliti dipandang sebagai instrumen kunci; 2. Penelitiannya bersifat deskriptif; 3. Lebih memperhatikan proses daripada hasil atau produk; 4. Dalam menganalisis data cenderung secara induktif; dan 5. Makna merupakan hal yang esensial dalam penelitian kualitatif. (Imron Arifin, 1996: 49-50)

Menurut Whitney penelitian deskriptif adalah pencarian fakta dengan interpretasi yang tepat, penelitian deskriptif mempelajari masalahmasalah dalam masyarakat, serta tata cara yang berlaku dalam masyarakat serta situasi-situasi tertentu, termasuk tentang hubungan, kegiatankegiatan, sikap-sikap, pandangan-pandangan, serta proses-proses yang sedang berlangsung dan pengaruh-pengaruh dari suatu fenomena (Moh. Nazir, 2003:55)

Selain itu metode deskriptif adalah upaya mendeskripsikan kondisi-kondisi yang sekarang ini terjadi (Mardalis, 1993:26). Penelitian deskriptif kualitatif dengan jenis penelitian studi kasus (case study) merupakan suatu penelitian yang dilakukan secara intensif, terinci dan mendalam terhadap suatu organisasi, lembaga atau gejala tertentu. Ditinjau dari wilayahnya, maka penelitian studi kasus hanya meliputi daerah atau subjek yang sempit, akan tetapi ditinjau dari sifat penelitian, penelitian studi kasus lebih mendalam.

\section{HASIL DAN PEMBAHASAN}

Merenungkan kembali arti makna kepemimpinan yang begitu panjang dalam kajian kepemimpinan pada teori di atas, setidaknya dapat disimpulkan bahwa kepemimpinan adalah jabatan formal, yang menuntut untuk mendapat fasilitas dan pelayanan dari konstituen yang seharusnya dilayani. Inilah yang kemudian menjadi menarik dalam konteks ke-Indonesiaan saat ini. Pemimpin dan penguasa menjadi satu dalam satu lembaga sehingga sulit dibedakan mana pemimpin sesungguhnya yang melayani rakyat dan mana penguasa yang dengan segala otoritasnya menggunakan kewenangan untuk 
membela dan mementingkan satu golongan daripada kepentingan umum dan rakyat. Hal ini terlihat ketika banyak di antara pemimpin atau penguasa yang memimin ketika dilantik mengatakan bahwa jabatan adalah sebuah amanah, namun dalam kenyataannya sedikit sekali atau bisa dikatakan hampir tidak ada pemimpin yang sungguh-sungguh menerapkan kepemimpinan dari hati, yaitu kepemimpinan yang melayani.

Perlu menjadi catatan untuk masyarakat Indonesia pada saat sekarang ini adalah bagaimana seorang pemimpin harus memiliki visi dalam membangun jiwa yang merdeka, mengubah cara pandang, pikiran, sikap, dan perilaku seluruh rakyat sekaligus pemimpinnya agar berorientasi pada kemajuan dan hal-hal yang modern, sehingga Indonesia menjadi bangsa yang besar dan mampu berkompetisi dengan bangsa-bangsa lain di dunia. Inilah yang kemudian dalam pandangan penulis ada korelasi dengan semangat revolusi mental untuk menuju Indonesia baru yang dengan pemimpin baru memiliki semangat baru membentuk karaktek orang Indonesia yang sesungguhnya menjadi bangsa yang besar dan berdaulat.

Kepemimpianan yang melayani dimulai dari dalam diri seorang pemimpin. Kepemimpinan menuntut suatu transformasi dari dalam hati dan perubahan karakter. Kepemimpinan yang melayani dimulai dari dalam dan kemudian bergerak keluar untuk melayani mereka yang dipimpinnya. Inilah mengapa kemudian Presiden Indonesia Ir. Joko Widodo serius menjadikan seorang pemimpin, baik dirinya maupun seluruh menteri dan pejabat menjadi pemimpin yang melayani dengan sepenuh hati kepada masyarakat Indonesia. Bahkan keseriusan menjadi pemimpin yang melayani menjadi gerakan nasional yang tertuang dalam Instruksi Presiden Nomor 12 Tahun 2016 tentang Gerakan Nasional Revolusi Mental. Inpres ini dikhususkan untuk memperbaiki serta membangun karakter bangsa Indonesia dalam melaksanakan revolusi mental. Tampak dalam Instruksi Presiden itu antara lain mengacu pada nilai-nilai integritas, etos kerja dan gotong royong untuk membangun budaya yang bermartabat, modern, maju, makmur dan sejahtera berdasarkan Pancasila. Tidak tanggung-tanggung Inpres ini juga ditunjukan kepada para Menteri Kabinet Kerja; Sekretaris Kabinet; Jaksa Agung Republik Indonesia; Panglima Tentara Nasional Indonesia; Kepala Kepolisian Negara Republik Indonesia (Kapolri); para kepala Lembaga Pemerintah Non Kementerian; Para Kepala Sekretariat Lembaga Negara; para gubernur; dan para bupati/walikota.

Dalam instruksi tersebut sangatlah jelas bahwa seluruh pejabat diminta untuk melakukan lima gerakan yaitu gerakan Indonesia Melayani, Bersih, Tertib, Mandiri dan Bersatu. Jelas dan sangat lugas bahwa hal pertama yang dilakukan adalah gerakan Indonesia melayani sebagai tolok ukur keberhasilan dari seluruh gerakan lainnya dan menjadi jiwa pada seluruh nilai-nilai utama instruksi tersebut. Tampak bahwa karakter melayani akan dapat terlihat dengan baik ketika menjadi ruh dan nafas dalam kehidupan seorang pemimpin yang bisa diterima rakyat. Disinilah pentingnya karakter dan integritas seorang pemimpin untuk menjadi pemimpin yang diterima oleh rakyat yang dipimpinnya.

Faktanya, apakah instruksi presiden dengan nilai-nalai utama tersebut benar-benar 
menjadi gaya hidup para pemimpin bangsa Indonesia. Ternyata tidak sedikit dari pemimpin yang mengaku wakil rakyat ataupun pejabat publik, justru tidak memiliki integritas dan nilainilai yang diinstruksikan tersebut. Hal ini karena apa yang diucapkan dan dijanjikan ketika kampanyekan para pemimpin yang sudah jadi saat ini, tidak sama dengan yang dilakukan ketika sudah duduk nyaman di kursinya.

Setidaknya ada sejumlah ciri -ciri dan nilai yang muncul dari seorang pemimpin yang memiliki hati yang melayani, yaitu tujuan utama seorang pemimpin adalah melayani kepentingan mereka yang dipimpinnya. Orientasinya adalah bukan untuk kepentingan diri pribadi maupun golongan tapi justru kepentingan publik yang dipimpinnya. Inilah yang dalam pandangan penulis tertuang dalam spirit Nawacita untuk Indonesia sebagai bentuk nyata model pemimpin yang melayani. Secara sederhana semangat ini yang harus diperhatikan banyak pihak, bukan karena presiden yang berkuasa pada saat ini tetapi memang cita-cita luhur tersebutlah yang menjadi upaya bersama untuk mewujudkannya yaitu; Pertama; Menghadirkan kembali Negara untuk melindungi segenap dan memberikan rasa aman pada suluruh warga Negara. Kedua; Membuat Pemerintah tidak absen dengan membangun tata kelola Pemerintah yang bersih, efektif, demokratis dan terpercaya. Ketiga; Membangun Indonesia dari pinggiran dengan memperkuat daerah-daerah dan desa dalam kerangka Negara kesatuan. Keempat; Menolak Negara lemah dengan melakukan reformasi system dan penegakan hukum yang bebas korupsi, bermartabat dan terpercaya. Kelima; Meningkatka kualitas hidup manusia. Keenam;
Mewujudkan melalui peningkatan kualitas pendidikan dan pelatihan dengan program Indonesia Pintar, Indonesia Kerja dan Indonesia Sejahtera.kemandirian ekonomi dengan menggerakkan sektor-sektor strategis ekonomi domestik. Ketujuh; Meningkatkan produktivitas rakyat dan daya saing di pasar internasional. Kedelapan; Melakukan revolusi karakter bangsa melalui kebijakan penataan kembali kurikulum pendidikan nasional dengan mengedepankan aspek pendidikan kewarganegaraan, yang menempatkan secara proporsional aspek pendidikan, seperti pengajaran sejarah pembentukan bangsa, nilai-nilai patriotisme dan cinta Tanah Air, semangat bela negara dan budi pekerti di dalam kurikulum pendidikan Indonesia. Kesembilan; Memperteguh ke-bhinekaan dan memperkuat restorasi sosial Indonesia melalui kebijakan memperkuat pendidikan ke-bhinekaan.

Pemimpin yang hebat bukan sekedar pemimpin yang memiliki banyak pengikut dan dilingkari dengan orang-orang yang mematuhi setiap saat. Bahkan sesungguhnya pemimpin sejati yang senang melayani memiliki kerinduan untuk membangun dan mengembangkan mereka yang dipimpinnya sehingga tumbuh banyak pemimpin dalam kelompoknya. Keberhasilan seorang pemimpin sangat tergantung dari kemampuannya untuk membangun orang - orang di sekitarnya, karena keberhasilan sebuah organisasi sangat tergantung pada potensi sumber daya manusia dalam organisasi tersebut. Jika sebuah organisasi atau masyarakat mempunyai banyak anggota dengan kualitas pemimpin, organisasi atau bangsa tersebut akan berkembang dan menjadi kuat. Hal ini dikarenakan karakter dirinya yang kuat berupa 
kualitas kepribadian yang handal. Kualitas itu antara lain pertama; Integritas sebagai sebuah kualitas kujujuran, Kedua; Sosiabilitas yaitu kecenderungan pemimpin untuk menjalin hubungan yang menyenangkan, Ketiga; Intelijensi - dimana seorang pemimpin memiliki potensi dalam kemampuan bicara, menafsir, dan bernalar yang lebih kuat ketimbang yang bukan pemimpin. Keempat; Kepercayaan Diri akan kompetensi dan keahlian yang dimiliki, dan juga meliputi harga diri serta keyakinan diri dan Kelima; Determinasi-hasrat menyelesaikan pekerjaan yang meliputi ciri seperti berinisiatif, kegigihan, dan mempengaruhi.

Kehadiran seorang pemimpin yang melayani dengan seluruh jiwa dan raganya akan sangat dirindukan oleh seluruh lapisan dan menjadi kekuatan bagi rakyat dalam menjalankan seluruh kebijakan yang dikeluarkannya karena pemimpin yang demikian memiliki kasih dan perhatian kepada mereka yang dipimpinnya. Rakyat akan senantiasa mematuhi karena kasih itu mewujud dalam bentuk kepedulian akan kebutuhan, kepentingan, impian dan harapan dari mereka yang dipimpinnya.

Pemimpin yang melayani adalah pemimpin yang mau mendengar setiap kebutuhan, impian, dan harapan dari mereka yang dipimpin. Pemimpin yang melayani adalah pemimpin yang dapat mengendalikam ego dan kepentingan pribadinya melebihi kepentingan bersama atau mereka yang dipimpinnya. Mengendalikan ego berarti dapat mengendalikan diri ketika tekanan maupun tantangan yang dihadapi menjadi begitu berat,selalu dalam keadaan tenang, penuh pengendalian diri, dan tidak mudah emosi.
Seorang pemimpin tidak cukup hanya memiliki hati atau karakter semata, tapi juga harus memiliki serangkaian metode kepemimpinan agar dapat menjadi pemimpin yang efektif. Banyak sekali pemimpin memiliki kualitas sari aspek yang pertama yaitu karakter dan integritas seorang pemimpin, tetapi ketika menjadi pimpinan formal, justru tidak efektif sama sekali karena tidak memiliki metode kepemimpinan yang baik. Contoh adalah para pemimpin yang diperlukan untuk mengelola mereka yang dipimpinnya..

Tidak banyak pemimpin yang memiliki metode kepemimpinan ini. Karena hal ini tidak pernah diajarkan di sekolah - sekolah formal. Keterampilan seperti ini disebut dengan Softskill atau Personalskill. Namun setidaknya seorang pemimpin harus memiliki karakter kepemimpinan berikut:

Pertama; Kepemimpinan yang efektif dimulai dengan visi yang jelas. Visi ini merupakan sebuah daya atau kekuatan untuk melakukan perubahan, yang mendorong terjadinya proses ledakan kreatifitas yang dahsyat melalui integrasi maupun sinergi berbagai keahlian dari orang orang yang ada dalam organisasi tersebut. Inilah ide dasar dari digaungkannya kembali gerakan revolusi mental oleh Presiden Joko Widodo. Jiwa bangsa yang terpenting adalah jiwa merdeka, jiwa kebebasan untuk meraih kemajuan. Jiwa merdeka disebut Presiden Jokowi sebagai positivisme.

Kedua; Seorang pemimpin yang efektif adalah seorang yang responsive. Artinya dia selalu tanggap terhadap setiap persoalan, kebutuhan, harapan, dan impian dari mereka yang dipimpin. Selain itu selalu aktif dan proaktif dalam mencari solusi dari setiap permasalahan ataupun tantangan yang dihadapi. Dalam 
kehidupan sehari-hari, praktek revolusi mental adalah menjadi manusia yang berintegritas, mau bekerja keras, dan punya semangat gotong royong. Para pemimpin dan aparat negara akan jadi pelopor untuk menggerakkan revolusi mental, dimulai dari masing-masing Kementerian/Lembaga (K/L). Sebagai pelopor gerakan revolusi mental, pemerintah lewat $\mathrm{K} / \mathrm{L}$ harus melakukan tiga hal utama yaitu; bersinergi, membangun manajemen isu, dan terakhir penguatan kapasitas aparat negara.

Ketiga; Seorang pemimpin yang efektif adalah seorang pelatih atau pendamping bagi orang - orang yang dipimpinnya. Artinya dia memiliki kemempuan untuk menginspirasi, mendorong dan memampukan anak buahnya dalam menyusun perencanaan (termasuk rencana kegiatan, target atau sasaran, rencana kebutuhan sumber daya, dsb), melakukan kegiatan sehari - hari seperti monitoring dan pengendalian, serta mengevaluasi kinerja dari anak buahnya.

Gerakan revolusi mental terbukti berdampak positif terhadap kinerja pemerintahan Jokowi. Dalam waktu yang tidak terlalu lama, ada banyak prestasi yang diraih berkat semangat integritas, kerja keras, dan gotong royong dari aparat negara dan juga masyarakat.

Setidaknya inilah beberapa hal hal perilaku seorang pemimpin yang akan menbawa bangsa ini mandiri:

1. Pemimpin tidak hanya sekedar memuaskan mereka yang dipimpin, tapi sungguh sungguh memiliki kerinduan senantiasa untuk memuaskan Tuhan. Seorang pemimpin tidak hanya cerdas secara personal dalam hubungan horizontal terhadap manusia tetapi juga cerdas secara spiritual dn vertikal kepada Tuhan. Artinya dia hidup dalam perilaku yang sejalan dengan firman Tuhan. Dia memiliki misi untuk senantiasa memuliakan Tuhan dalam setiap apa yang dipikirkan, dikatakan, dan diperbuatnya.

2. Pemimpin fokus pada hal - hal spiritual dibandingkan dengan sekedar kesuksesan duniawi. Baginya kekayaan dan kemakmuran adalah untuk dapat memberi dan beramal lebih banyak. Apapun yang dilakukan bukan untuk mendapat penghargaan, tapi melayani sesamanya. Dan dia lebih mengutamakan hubungan atau relasi yang penuh kasih dan penghargaan, dibandingkan dengan status dan kekuasaan semata. Inilah yang juga setidaknya sudah dicapai oleh pemerintah Indonesia dengan keberhasilan pada pemberantasan ilegal fishing, pengelolaan BBM lebih bersih dan transparan, pembangunan pembangkit listrik terbesar di Asia Tenggara, pembangunan tol trans Jawa, trans Sumatera, dan Kalimantan, adalah sedikit hasil dari kerja keras pemerintah Presiden Jokowi. Ke depan, gerakan revolusi mental akan semakin digalakkan agar sembilan agenda prioritas pemerintah yang tertuang dalam Nawa Cita bisa terwujud. (Tim PKP-Kemenkominfo)

3. Pemimpin sejati senantiasa mau belajar dan bertumbuh dalam berbagai aspek, baik pengetahuan, kesehatan, keuangan, relasi, dsb. Setiap harinya senantiasa menyelaraskan (recalibrating ) dirinya terhadap komitmen untuk melayani Tuhan dan sesama. 
Demikian kepemimpinan yang melayani dengan karakter integritas, terbuka, mampu menerima kritik, rendah hati, mampu memahami spiritualitas yang tinggi, dan selalu mengupayakan yang terbaik bagi diri mereka sendiri maupun bagi orang lain.

Pada akhirnya kepemimpinan adalah sebuah keputusan dan lebih merupakan hasil dari proses perubahan karakter atau tranformasi internal dalam diri seseorang. Kepemimpinan bukanlah jabatan atau gelar, melainkan sebuah kelahiran dari proses panjang perubahan dalam diri seseorang. Ketika seseorang menemukan visi dan misi hidupnya, ketika terjadi kedamaian dalam diri (inner peace) dan membentuk bangunan karakter yang kokoh, ketika setiap ucapan dan tindakannya mulai memberikan pengaruh kepada lingkungannya, dan ketika keberadaannya mendorong perubahan dalam organisasinya, pada saat itulah seseorang lahir menjadi pemimpin sejati. Jadi pemimpin bukan sekedar gelar atau jabatan yang diberikan dari luar melainkan sesuatu yang tumbuh dan berkembang dari dalam diri seseorang. Kepemimpinan lahir dari proses internal (leadership from the inside out ).

Kepemimpinan sesungguhnya tidak ditentukan oleh pangkat atau jabatan seseorang. Kepemimpinan adalah sesuatu yang muncul dari dalam dan merupakan buah dari keputusan seseorang untuk mau menjadi pemimpin, baik bagi dirinya sendiri, bagi keluarga, bagi lingkungan pekerjaan, maupun bagi lingkungan sosial dan bahkan bagi negerinya.

Pemimpin sejati adalah seorang pemberi semangat (encourager), motivator, inspirator, dam maximizer.Konsep pemikiran seperti ini adalah sesuatu yang baru dan mungkin tidak bisa diterima oleh para pemimpin konvensional yang justru mengharapkan penghormatan dan pujian.

\section{KESIMPULAN DAN SARAN}

\section{Kesimpulan}

Kata pemimpin, kepemimpinan serta kekuasaan memiliki keterikatan yang tak dapat dipisahkan. Karena untuk menjadi pemimpin bukan hanya berdasarkan suka satu sama lainnya, tetapi banyak faktor. Pemimpin yang berhasil hendaknya memiliki beberapa kriteria yang tergantung pada sudut pandang atau pendekatan yang digunakan, apakah itu kepribadiannya, keterampilan, bakat, sifat sifatnya, atau kewenangannya yang dimiliki yang mana nantinya sangat berpengaruh terhadap teori maupun gaya kepemimpinan yang akan diterapkan.

Rahasia utama kepemimpinan adalah kekuatan terbesar seorang pemimpin bukan dari kekuasaanya, bukan kecerdasannya, tapi dari kekuatan pribadinya. Seorang pemimpin sejati selalu bekerja keras memperbaiki dirinya sebelum sibuk memperbaiki orang lain. Pemimpin bukan sekedar gelar atau jabatan yang diberikan dari luar melainkan sesuatu yang tumbuh dan berkembang dari dalam diri seseorang. Kepemimpinan lahir dari proses internal (leadership from the inside out).

\section{Saran}

Sangat diperlukan sekali jiwa kepemimpinan pada setiap pribadi manusia. Jiwa kepemimpinan itu perlu selalu dipupuk dan dikembangkan. Paling tidak untuk memimpin diri sendiri. 
Jika seluruh lembaga dan institusi negeri ini memiliki pemimpin yang sangat tangguh tentu akan menjadi luar biasa pada pengelolaan lembaga tersebut. Selain itu dengan pemimpin yang baik maka akan terwujud pula situasi yang baik, kerjasama, dan pola interaksi yang baik antar masing-masing individu.

\section{DAFTAR PUSTAKA}

Gary Yukl, Leadership in Organizations, Sixth Edition (Delhi : Dorling Kindersley, 2009)

George R. Goethals, eds., et.al., Encyclopedia of Leadership, (Thousand Oaks: SAGE Publications, 2004)

http://presidenri.go.id/ulasan/revolusi-mental.html

http://setabasri01.blogspot.co.id/2011/01/kepemi mpinan-dalam- organisasi. html

https://www.kominfo.go.id/content/detail/5932/rev olusi-mental- memba ngun-jiwamerdeka-menuju-bangsabesar/0/artikel_gpr

Imron Arifin, Penelitian Kualitatif dalam IImu-IImu Sosial dan Keagamaan, Malang: Kalimasahada Press, 1996

Mardalis, Metode Penelitian Suatu Pendekatan Proposal, Jakarta: Bumi Aksara, 1993

Moh. Nazir, Metode Penelitian, Jakarta: Ghalia Indonesia, 2003

Lexi J. Moleong, Metode Penelitian Kualitatif, Bandung: Remaja Rosda Karya, 2002.

M. Ali, Penelitian Kependidikan dan Strategi, Bandung: Angkasa, 1987

Robert N. Lussier and Christopher F. Achua, Leadership : Theory, Application, and Skill Development, $4^{\text {th }}$ Edition (Mason, Ohio : South-Western Cengage Learning, 2010)
Stephen P. Robbins, Essentials of Organization Behavior, $7^{\text {th }}$ Edition (New Jersey : Pearson Education, Inc., 2003) 